\title{
GROWTH, NUTRIENTS UPTAKE AND GRAIN YIELD OF SOME WHEAT CULTIVARS AS AFFECTED BY ZINC APPLICATION UNDER SANDY SOIL CONDITIONS \\ El-Metwally, A. EL-M. ${ }^{1}$; N. A. Khalili'; M. M. El-Fouly ${ }^{2}$ and M. F. El-Dahshouri² \\ 1. Agronomy Dept., Fac. of Agric., Cairo Univ. \\ 2. Fertilization Technology Dept., National Research Centre (NRC). Dokki- Cairo-Egypt
}

\begin{abstract}
Two field experiments were carried out at Ismailia Exp. Sta., Agric. Res. Center, Ismailia governorate, during $2007 / 2008$ and 2008/2009 seasons to study the influence of zinc application on growth, yield and yield components of some wheat (Triticum aesitivum L.) cultivars (Sakha-93, Sakha-94, Giza-168, Gemmeiza-9 and Gemmeiza-10). Three levels of $\mathrm{Zn}$ were applied: 0.0 (control), 1.5 and $3.0 \mathrm{~kg} \mathrm{Zn}$ per Fed. Results showed that positive significant effects on growth traits, grain yield and its attributes was achieved by fertilizing wheat cultivars with $3.0 \mathrm{~kg} \mathrm{Zn/fed}$. Also, application of $3.0 \mathrm{~kg} \mathrm{Zn/fed}$. showed the highest values of $P, K, Z n$ and $F e$ of shoot content. The largest flag leaf area was that of Sakha-93 and Gemmeiza-9 while, Giza168 had superior shoot dry weight. Sakha-94 cultivar significantly surpasses all cultivars in plant height, while Gemmeiza-10 gave the highest number of spikes $/ \mathrm{m}^{2}$ while 1000-grain weight of Sakha-93 was the largest. The highest grain yield was achieved with Sakha-94 and Gemmeiza-9.

Keywords: Wheat (Triticum aestivum L.) cultivars, Zinc Soil application, Yield, Growth, Uptake and Sandy soil.
\end{abstract}

\section{INTRODUCTION}

Zinc is one of the most important micronutrient limiting crop growth and productivity (Lindsay 1972). Zinc is an important component of various enzymes that are responsible for driving many metabolic reactions in plants. In addition, zinc is a co-factor over 300 enzymes and proteins involved in cell division, nucleic acid metabolism and protein biosynthesis (Marschner, 1995).

Zinc deficiency in soils has been reported worldwide, particularly in calcareous soils of arid and semiarid regions (Takkar and Walker, 1993). Zinc deficiency can be corrected by applying $\mathrm{Zn}$ as soil or foliar application. Chelated and mineral forms of $\mathrm{Zn}$ can be used to correct $\mathrm{Zn}$ deficiency. Zinc sulphate $\left(\mathrm{ZnSO}_{4}\right)$ is the most common source of zinc fertilizer because of its high solubility in water, and its low cost compared to synthetic $\mathrm{Zn}$ chelates such as Zn-EDTA (Mordvedt and Gilkes, 1993).

Zinc status in some soils in Egypt, i.e. sandy and calcareous revealed that, mostly, insufficient (low/deficient) (El-Fouly et al. 1984), and they pointed out that if the values of available zinc in soil are higher than the critical values, these does not necessarily indicate sufficiency for the plant because there are many environmental and soil factors such as high $\mathrm{pH}$, high concentrations of $\mathrm{Ca}, \mathrm{Mg}$ and $\mathrm{P}$ in soil solution which affect zinc uptake. 
Cereal crops occupy a prime position in providing food for human consumption. Almost $50 \%$ of the soil used for cereal production in world contains a low level of plant available zinc which reduces grain yield (Graham and Welch 1996).

Increasing wheat (Triticum aestivum L.) productivity is a national target to cope with the social and economic obligations that are the normal consequences of the continued high rates of population growth and to fill up the gap between production and consumption. This urgent need requires continuous scientifically based implementation of effective agricultural practices on the limited cultivable land area and to increase production through cultivation of desert sandy soil under appropriate agronomic practices. Extending agriculture to desert land is one of the major components of the national agricultural strategy to increase agricultural production in Egypt.

The strategy of Ministry of Agriculture is to increase the cultivated wheat area in the newly reclaimed lands and breeding high yielding varieties. Wheat cultivars differed in growth characters (Hassanein et al. 1997; Hassanein 2001; Ahmed et al. 2006 and EL-Habbasha et al. 2008). Wheat cultivars differed in yield and its components (Hassanein and Gomaa 2001; Ahmed et al. 2006 and EL-Habbasha et al. 2008).

The purpose of this study was to explore the response of wheat cultivars to zinc levels to achieve the highest grain yield of five wheat cultivars under sandy soil condition.

\section{MATERIALS AND METHODS}

Two field experiments were carried out at Ismailia Exp. Sta., Agric. Res. Center (ARC), Ismailia governorate, Egypt during 2007/2008 and $2008 / 2009$ seasons to study the influence of zinc efficiency on growth, yield and yield components of wheat (Triticum aesitivum L.) cvs. Sakha-93, Sakha94, Giza-168, Gemmeiza-9 and Gemmeiza-10.

Treatments:

1. No addition of $\mathrm{Zn}$ (control)

2. $1.5 \mathrm{~kg} \mathrm{Zn} \mathrm{/} \mathrm{fed.}$

3. $3.0 \mathrm{~kg} \mathrm{Zn} \mathrm{/} \mathrm{fed.}$

Zinc doses were added as soil application in form of zinc sulphate $\mathrm{Zn}$ $\mathrm{SO}_{4} .7 \mathrm{H}_{2} \mathrm{O}(22 \% \mathrm{Zn})$ at 30 days after sowing (DAS).

Soil was ploughed using a chisel plough and divided into experimental units, $3.0 \mathrm{~m}$ long and $3.5 \mathrm{~m}$ wide. Wheat grains were sown on November $22^{\text {th }}$ and $11^{\text {th }}$ in $2007 / 2008$ and $2008 / 2009$ seasons, respectively at the rate of $60 \mathrm{~kg} / \mathrm{fed}$. in rows spaced $20 \mathrm{~cm}$. Representative soil samples were taken after soil preparation and before fertilization from the experimental sites (0-30 cm depth) for determining physico-chemical characteristics. Soil evaluation was done according to Ankerman and Large, (1974).

Nitrogen, phosphorus and potassium were added at rate of $106 \mathrm{~kg}$ $\mathrm{N} / \mathrm{fed}, 37 \mathrm{~kg} \mathrm{P} \mathrm{O}_{5} / \mathrm{fed}$. and $24 \mathrm{~kg} \mathrm{~K}{ }_{2} \mathrm{O} / \mathrm{fed}$., respectively. Nitrogen was applied 
as ammonium sulfate $(20.6 \% \mathrm{~N})$ in three equal splits at planting, 30 and 50 days age in both seasons. Phosphorus was applied as a single super phosphate $\left(15.5 \% \mathrm{P}_{2} \mathrm{O}_{5}\right)$ during soil preparation. Potassium was applied as Potassium sulphate $\left(50 \% \mathrm{~K}_{2} \mathrm{O}\right)$ at 30 days after sowing. The whole experimental plots were also sprayed with mixed iron; manganese and copper in EDTA form at 45 and 60 days after planting at rate of $0.5 \mathrm{~g} / \mathrm{L}$. from each nutrient. Plants were irrigated at 6 days interval using sprinkler system.

At 90 days after sowing, a sample of wheat shoots was taken to determine flag leaf area (Length $x$ maximum width $x$ 0.79) according to Voldeng and Simpson (1967), dry weight /plant, macro and micronutrients content in shoots. The samples were washed with tap water, $0.01 \mathrm{~N} \mathrm{HCl}$ acidified bi-distilled water and bi-distilled water, respectively, then oven dried at $70^{\circ} \mathrm{C}$ for 24 hours and ground. The ground material was dry-ashed in a muffle furnace at $450^{\circ} \mathrm{C}$ for 6 hours.

Phosphorus was photometrical determined using the molybdatevanadate method (Jackson, 1973). Potassium was measured using Dr. Lang -M8D Flame-photometer. Fe and $\mathrm{Zn}$ were determined using the Atomic Absorption Spectrophotometer (Perkin-Elmer 100 B).

At maturity, 140 days after planting the plants were harvested. Sample of $\mathrm{m}^{2}$ wheat plants were taken to determine plant height, number of Shoots per $\mathrm{m}^{2}$, number of spikes per $\mathrm{m}^{2}$, number of grains per spike, 1000 grains weight. Grain yield was determined in one $\mathrm{m}^{2}$ then, converted to fed. (fed. $=4200 \mathrm{~m}^{2}$ ).

The experimental design was split plot in randomized complete block design with four replicates. The results were submitted to an analysis of variance ANOVA according to Snedecor and Cochran, (1967). Differences among treatments were determined as using LSD test at a significance level of 0.05 according to Waller and Duncan (1969).

\section{RESULTS AND DISSCUSSION}

\section{Experimental soil presentation}

Results of the experiment soil was sand in texture, very high alkalinity in reaction, had low content of macro and micronutrients. The soil was poor in organic matter, without any salinity problems.

\section{Varietal differences}

2.1. Growth parameters: Growth parameters of five wheat cultivars are shown in (Table1).There were significant differences between wheat cultivars in flag leaf area and dry weight of shoot at 90 days after sowing. The largest flag leaf area was that of Sakha-93 and Gemmeiza-9 cultivars. While, Giza 168 cultivars had superior shoot dry weight. The varietal differences between wheat cultivars may be due to the genetical differences between genotypes concerning partition of dry matter, where wheat cultivars differed in carbon equivalent, yield energy per plant and per area unit (Abd EL-Gawad et al., 
1987). Similar results were obtained by Hassanein (2001), Zaki et al. (2004), Ahmed et al. (2006) and El-Habbasha et al. (2008).

2.2. Macro- and micronutrients status: Data in (Table 1) include the macroand micronutrients content in shoots of different wheat cultivars. This data show significant differences between cultivars in $\mathrm{P}, \mathrm{K}, \mathrm{Fe}$ and $\mathrm{Zn}$ content. Giza-168 wheat cultivar was the highest in its content of $\mathrm{P}, \mathrm{K}, \mathrm{Zn}$ and $\mathrm{Fe}$.

2.3. Yield and yield components: As shown in (Table 2) significant variation between cultivars was observed in plant height, number of shoots $/ \mathrm{m}^{2}$, number of spikes $/ \mathrm{m}^{2}$, number of grains/ spike, 1000-grain weight and grain yield /fed. for both seasons, except plant height ( $1^{\text {st }}$ season) the differences did not reach the level of significance. Sakha-94 cultivar gave the highest number of shoots, number of spike and grains per spike in second season, while, Giza-168 gave the highest in number of shoots and number of spike in first season. Results of grain yield/fed. showed a significant difference between cultivars, the highest grain yield 13.4 and $16.9 \mathrm{ardab} / \mathrm{fed}$. (Ardab= $150 \mathrm{~kg}$ ) were obtained with Sakha-94 and Gemmeiza-9 in the first and second seasons, respectively.

Table 1. Effect of cultivars on flag leaf area, dry weight/ plant and macro and micronutrient content of some bread wheat cultivars at 90 DAS during 2007/2008 $\left(1^{\text {st }}\right)$ and $2008 / 2009\left(2^{\text {nd }}\right)$ seasons.

\begin{tabular}{|c|c|c|c|c|c|c|c|c|c|c|c|c|}
\hline \multirow{4}{*}{ Cultivars } & \multirow{3}{*}{\multicolumn{2}{|c|}{$\begin{array}{c}\text { Flag leaf } \\
\text { area } \\
\left(\mathrm{cm}^{2}\right)\end{array}$}} & \multirow{3}{*}{\multicolumn{2}{|c|}{$\begin{array}{l}\text { Dry wt. } \\
\text { / plant } \\
\text { (g) }\end{array}$}} & \multicolumn{8}{|c|}{ Macro and micronutrient content/ plant } \\
\hline & & & & & \multicolumn{2}{|c|}{$\mathbf{P}$} & \multirow{2}{*}{\multicolumn{2}{|c|}{$\mathbf{K}$}} & \multicolumn{2}{|c|}{$\mathbf{Z n}$} & \multicolumn{2}{|c|}{$\mathrm{Fe}$} \\
\hline & & & & & & & & & & & & \\
\hline & $1^{\text {st }}$ & $2^{\text {nd }}$ & $1^{\text {st }}$ & $2^{\text {nd }}$ & $1^{\text {st }}$ & $2^{\text {nd }}$ & $1^{\text {st }}$ & $2^{\text {nd }}$ & $1^{\text {st }}$ & $2^{\text {nd }}$ & $1^{\text {st }}$ & $2^{\text {nd }}$ \\
\hline Sakha-93 & 24.8 & 31.3 & 4.4 & 3.1 & 3.7 & 6.6 & 72 & 70 & 140 & 83 & 292 & 266 \\
\hline Sakha-94 & 21.8 & 28.8 & 4.7 & 3.2 & 3.5 & 7.2 & 87 & 72 & 156 & 89 & 271 & 315 \\
\hline Giza-168 & 24.7 & 30.6 & 5.5 & 3.4 & 4.7 & 7.0 & 99 & 64 & 157 & 96 & 309 & 255 \\
\hline Gemmeiza-9 & 20.4 & 36.7 & 4.9 & 3.3 & 4.1 & 7.1 & 79 & 83 & 143 & 83 & 289 & 321 \\
\hline Gemmeiza-10 & 23.1 & 36.0 & 4.9 & 3.1 & 4.2 & 6.1 & 79 & 70 & 156 & 80 & 293 & 286 \\
\hline L.S.D at 0.05 & 1.5 & 3.5 & 0.2 & 0.2 & 0.8 & 0.6 & 14 & 7 & 12 & 6 & 15 & 24 \\
\hline
\end{tabular}

Table 2. Effect of cultivars on Plant height, shoots number, yield and yield components of some bread wheat cultivars during $2007 / 2008$ and $2008 / 2009$ seasons.

\begin{tabular}{|c|c|c|c|c|c|c|c|c|c|c|c|c|}
\hline \multirow[t]{2}{*}{ Cultivars } & \multicolumn{2}{|c|}{$\begin{array}{c}\text { Plant } \\
\text { height } \\
(\mathrm{cm})\end{array}$} & \multicolumn{2}{|c|}{$\begin{array}{c}\text { Shoots } \\
/ \mathrm{m}^{2} \\
\text { (no) }\end{array}$} & \multicolumn{2}{|c|}{$\begin{array}{c}\text { Spikes } \\
/ \mathrm{m}^{2} \\
\text { (no) }\end{array}$} & \multicolumn{2}{|c|}{$\begin{array}{l}\text { Grains } \\
\text { / spike } \\
\text { (no) }\end{array}$} & \multicolumn{2}{|c|}{$\begin{array}{c}1000 \\
\text { grains } \\
\text { (g) }\end{array}$} & \multicolumn{2}{|c|}{$\begin{array}{c}\text { Grain } \\
\text { yield /fed.) } \\
\text { (ardab }\end{array}$} \\
\hline & $1^{\text {st }}$ & $2^{\text {nd }}$ & $1^{\text {st }}$ & $2^{\text {nd }}$ & $1^{\text {st }}$ & $2^{\text {nd }}$ & $1^{\text {st }}$ & $2^{\text {nd }}$ & $1^{\text {st }}$ & $2^{\text {nd }}$ & $1^{\text {st }}$ & $2^{\text {nd }}$ \\
\hline Sakha-93 & 85.2 & 73.8 & 760 & 691 & 597 & 517 & 34.1 & 36.1 & 36.5 & 39.2 & 11.9 & 16.3 \\
\hline Sakha-94 & 91.0 & 87.9 & 754 & 791 & 592 & 576 & 34.3 & 36.0 & 36.0 & 36.9 & 13.4 & 15.0 \\
\hline Giza-168 & 88.4 & 83.4 & 887 & 777 & 657 & 545 & 31.3 & 35.9 & 33.7 & 34.2 & 12.0 & 15.2 \\
\hline Gemmeiza-9 & 89.9 & 83.7 & 813 & 749 & 632 & 550 & 31.2 & 34.3 & 37.5 & 38.2 & 11.8 & 16.9 \\
\hline Gemmeiza-10 & 88.6 & 76.5 & 751 & 725 & 594 & 573 & 32.5 & 36.1 & 37.5 & 38.0 & 12.8 & 14.7 \\
\hline L.S.D at 0.05 & N.S & 2.9 & 42 & 33 & 26 & 19 & 1.5 & 0.8 & 0.9 & 0.8 & 0.3 & 0.9 \\
\hline
\end{tabular}

Varietal differences between wheat cultivars may be due to genetical differences between cultivars, as well as, the range of cultivar response. It is noteworthy to mention that differences in yield potential of wheat depend undoubtedly on the part of photosynthetic partitioned into grain yield as 
reported by Welch et al. (1991). Abd El- Gawad et al., (1987) found that wheat cultivars differed in partitioning and migration of the total available photosynthate to economic yields. These results were in harmony with the results obtained by Hassanein (2001), Hassanein and Gomaa (2001), Sarhan and Abd El-Maksoud (2002), Zaki et al. (2004), Ahmed et al. (2006) and ElHabbasha et al. (2008).

\section{Effect of Zinc soil application}

3. 1. Growth parameters: Data presented in (Table 3) indicate that flag leaf area and dry weight of shoots were significantly affected by soil application of zinc in both seasons except flag leaf area in the first season where the differences between treatments did not reach to the significantly. Increasing zinc soil application from 0.0 up to 1.5 and $3.0 \mathrm{~kg} \mathrm{Zn} \mathrm{/} \mathrm{fed.} \mathrm{led} \mathrm{to} \mathrm{decrease}$ flag leaf area by 3.7 and $14.2 \%$ for wheat plants in the second season, respectively.

These results ought to drought conditions during developing stage, may have a negative effect on flag leaf area functions i.e number of cells through cell division and enhancing cell size through cell enlargement and turgidity, as reported by Pugnaire et al. (1994). It was observed that applying $3.0 \mathrm{~kg}$ $\mathrm{Zn} / \mathrm{fed}$. produced the highest D.W per plant (5.64 and $3.91 \mathrm{~g} / \mathrm{plant}$ ) at 90 days after sowing for both seasons, respectively.

3.2. Macro- and micronutrients status: Data of $P, K, F e$ and $Z n$ uptake in wheat shoots show significant response to soil zinc application (Table 3).

Table 3. Effect of zinc soil applications on growth characteristics and macro and micronutrients contents of some bread wheat cultivars at 90 DAS during 2007/2008 and 2008/2009 seasons.

\begin{tabular}{|c|c|c|c|c|c|c|c|c|c|c|c|c|}
\hline \multirow{4}{*}{ Treatments } & \multirow{3}{*}{\multicolumn{2}{|c|}{$\begin{array}{c}\text { Flag leaf area } \\
\left(\mathrm{cm}^{2}\right)\end{array}$}} & \multirow{3}{*}{\multicolumn{2}{|c|}{$\begin{array}{l}\text { Dry wt. } \\
\text { (g/plant) }\end{array}$}} & \multicolumn{8}{|c|}{ Macro and micronutrients contents/ plant } \\
\hline & & & & & \multicolumn{2}{|c|}{$\mathbf{P}$} & \multirow{2}{*}{\multicolumn{2}{|c|}{$\mathbf{K}$}} & \multicolumn{2}{|c|}{$\mathrm{Zn}$} & \multicolumn{2}{|c|}{$\mathrm{Fe}$} \\
\hline & & & & & \multicolumn{2}{|c|}{ (mg) } & & & \multicolumn{4}{|c|}{$(\mu \mathrm{g})$} \\
\hline & $1^{\text {st }}$ & $2^{\text {nd }}$ & $1^{\text {st }}$ & $2^{\text {nd }}$ & $1^{\text {st }}$ & $2^{\text {nd }}$ & $1^{\text {st }}$ & $2^{\text {nd }}$ & $1^{\text {st }}$ & $2^{\text {nd }}$ & $1^{\text {st }}$ & $2^{\text {nd }}$ \\
\hline Control & 22.0 & 34.5 & 4.3 & 2.8 & 3.3 & 5.6 & 72 & 61 & 113 & 74 & 209 & 263 \\
\hline $1.5 \mathrm{~kg} \mathrm{Zn/fed.}$ & 21.9 & 33.3 & 4.7 & 2.9 & 4.0 & 6.3 & 81 & 64 & 141 & 75 & 301 & 286 \\
\hline $3.0 \mathrm{~kg} \mathrm{Zn/fed.}$ & 24.9 & 30.2 & 5.6 & 3.9 & 4.8 & 8.5 & 97 & 90 & 197 & 110 & 361 & 316 \\
\hline L.S.D at 0.05 & N.S & 1.31 & 0.2 & 0.1 & 0.8 & 1.2 & 10 & 10 & 9 & 5 & 24 & N.S \\
\hline
\end{tabular}

Application zinc with $3.0 \mathrm{~kg} / \mathrm{fed}$. gave the highest wheat shoots content of $\mathrm{P}, \mathrm{K}, \mathrm{Fe}$ and $\mathrm{Zn}$ as compared with other treatments. This might be in part attributed to the favorable effect of zinc on vegetative plant materials which in turn increase $\mathrm{P}, \mathrm{K}, \mathrm{Fe}$ and $\mathrm{Zn}$ uptake by plants (Marschner, 1995). Micronutrients improved the performance of root growth and prevented the nutritional disorders and consequently caused increase in the uptake of nutrients (El-Fouly, et al. 2010).

3.3. Yield and yield components: Soil application with $\mathrm{Zn}$ had a favorable effect on shoots number $/ \mathrm{m}^{2}$, spikes number $/ \mathrm{m}^{2}$, grains number /spike, 1000-grain weight (g) and grain yield/fed. (ardab) as shown in (Table 4) in 2007/2008 and 2008/2009 seasons. However, the differences between 
treatments did not reach to the level of significance for plant height in both seasons.

Fertilizing wheat cultivars with $3.0 \mathrm{~kg} \mathrm{Zn} / \mathrm{fed}$. produced the greatest increase in spikes number $/ \mathrm{m}^{2}$, grains number/spike, 1000-grain weight and grains yield /fed. as compared with other treatments in both seasons. Such effect of soil application with $\mathrm{Zn}$ might be due to their critical role in crop growth, involving in photosynthesis processes, respiration and other biochemical and physiological activates and thus their importance in achieving higher yields. Similar results were reported by Khan, et al., 2008 who found that yield and its components were increased by the residual, direct and cumulative effect of $\mathrm{Zn}$ levels.

Table 4. Effect of zinc soil applications on plant height, shoots number, yield and yield components of some bread wheat cultivars during 2007/2008 and 2008/2009 seasons.

\begin{tabular}{|c|c|c|c|c|c|c|c|c|c|c|c|c|}
\hline \multirow[t]{2}{*}{ Treatments } & \multicolumn{2}{|c|}{$\begin{array}{l}\text { Plant } \\
\text { height } \\
\text { (cm) }\end{array}$} & \multicolumn{2}{|c|}{$\begin{array}{l}\text { Shoots } \\
/ \mathrm{m}^{2} \\
\text { (no) }\end{array}$} & \multicolumn{2}{|c|}{$\begin{array}{c}\text { Spikes } \\
/ \mathrm{m}^{2} \\
\text { (no) }\end{array}$} & \multicolumn{2}{|c|}{$\begin{array}{l}\text { Grains } \\
\text { / spike } \\
\text { (no) }\end{array}$} & \multicolumn{2}{|c|}{$\begin{array}{l}1000 \\
\text { grains } \\
\text { (g) }\end{array}$} & \multicolumn{2}{|c|}{$\begin{array}{c}\text { Grain } \\
\text { yield /fed. } \\
\text { (ardab) }\end{array}$} \\
\hline & $1^{\text {st }}$ & $2^{\text {nd }}$ & $1^{\text {st }}$ & $2^{\text {nd }}$ & $1^{\text {st }}$ & $2^{\text {nd }}$ & $1^{\text {st }}$ & $2^{\text {nd }}$ & $1^{\text {st }}$ & $2^{\text {nd }}$ & $1^{\text {st }}$ & $2^{\text {nd }}$ \\
\hline Control & \begin{tabular}{|l|}
87.7 \\
\end{tabular} & 80.9 & 818 & 771 & 563 & 499 & 31.2 & 34.9 & 35.0 & 35.1 & 12.0 & 14.9 \\
\hline $1.5 \mathrm{~kg} \mathrm{Zn} \mathrm{/fed.}$ & 89.3 & 81.6 & 818 & 776 & 595 & 521 & 33.4 & 34.9 & 35.8 & 38.1 & 12.3 & 15.6 \\
\hline $3.0 \mathrm{~kg} \mathrm{Zn} \mathrm{/fed.}$ & 88.9 & 80.7 & 743 & 693 & 684 & 637 & 35.5 & 35.6 & 37.9 & 38.7 & 12.8 & 16.4 \\
\hline L.S.D at 0.05 & N.S & N.S & 26 & 29 & 8 & 8 & 2.7 & 0.6 & 0.3 & 0.6 & 0.4 & 0.5 \\
\hline
\end{tabular}

\section{Effect of zinc $\times$ cultivars interaction}

4. 1. Growth parameters: The interaction between wheat cultivars and soil zinc application on flag leave area and dry weight of shoot was significant in both 2007/2008 and 2008/2009 seasons (Table 5). It is noteworthy to mention that soil zinc application with $3.0 \mathrm{~kg} / \mathrm{fed}$ on Giza-168 cultivar is considered to be the most favorable treatment of all mentioned characters in both growing seasons except in second season Gemmeiza-9 cultivar with 1.5 $\mathrm{kg} \mathrm{Zn} /$ fed. gave the highest value in flag leaf area $\left(38.48 \mathrm{~cm}^{2}\right)$. Zinc application improved FLA and DW (Judrth et al. 1977; Khan et al. 2008 and Zhoori et al. 2009).

4.2. Macro- and micronutrients status: The interaction between wheat cultivars and soil zinc application effect on $\mathrm{P}, \mathrm{K}, \mathrm{Zn}$ and Fe uptake of wheat shoot was significant in 2007/2008 and 2008/2009 seasons, except in first season for $\mathrm{P}$ and $\mathrm{K}$ uptake was not significant (Table 5). When Sakha-94 cultivar fertilized by $3.0 \mathrm{~kg} \mathrm{Zn/fed.} \mathrm{recorded} \mathrm{superiority} \mathrm{for} \mathrm{P}$ and $\mathrm{Zn}$ uptake of shoots in second and first season, respectively. Also, the highest values of $\mathrm{K}$ and $\mathrm{Fe}$ uptake in second and first season respectively were achieved when Gemmeiza-9 cultivar fertilized by $3.0 \mathrm{~kg} \mathrm{Zn/fed}$. Zinc application with high level $(3.0 \mathrm{~kg} / \mathrm{fed}$.) under different wheat cultivars gave the highest value of wheat shoots $\mathrm{P}, \mathrm{K}, \mathrm{Fe}$ and $\mathrm{Zn}$ uptake as compared with other treatments and soil fertility. This might be in part attributed to the favorable effect of zinc to form vegetative plant materials which in turn increase $\mathrm{P}, \mathrm{K}, \mathrm{Fe}$ and $\mathrm{Zn}$ uptake by plants. Marschner 1995 and Yilmaz et al. 1997 reported that foliar 
application of $\mathrm{Zn}$ can greatly enhance plant increase $\mathrm{Zn}$ concentration in flag leaves.

Table (5): Effect of interaction between cultivars and zinc application on growth characteristics and macro and micronutrients of some bread wheat cultivars at 90 DAS during 2007/2008 and 2008/2009 seasons

\begin{tabular}{|c|c|c|c|c|c|c|c|c|c|c|c|}
\hline \multirow{4}{*}{ Treat. } & \multirow{4}{*}{ Cultivars } & \multirow{3}{*}{\multicolumn{2}{|c|}{$\begin{array}{c}\text { Flag leaf } \\
\text { area } \\
\left(\mathrm{cm}^{2}\right)\end{array}$}} & \multirow{3}{*}{\multicolumn{2}{|c|}{$\begin{array}{l}\text { Dry wt } \\
\text { /plant } \\
\text { (g) }\end{array}$}} & \multicolumn{6}{|c|}{ Macro and micronutrients contents/ plant } \\
\hline & & & & & & $\mathbf{P}$ & $\mathbf{K}$ & & & & \\
\hline & & & & & & \multicolumn{2}{|c|}{ (mg) } & \multicolumn{4}{|c|}{$(\mu \mathrm{g})$} \\
\hline & & $1^{\text {st }}$ & $2^{\text {nd }}$ & $1^{\text {st }}$ & $2^{\text {nd }}$ & $2^{\text {nd }}$ & $2^{\text {nd }}$ & $1^{\text {st }}$ & $2^{\text {nd }}$ & $1^{\text {st }}$ & $2^{\text {nd }}$ \\
\hline \multirow{5}{*}{ Control } & Sakha-93 & 21.9 & 38.1 & 3.7 & 3.0 & 6.1 & 72 & 106 & 78 & 213 & 242 \\
\hline & Sakha-94 & 18.9 & 33.9 & 4.4 & 3.0 & 6.4 & 73 & 133 & 75 & 195 & 341 \\
\hline & Giza-168 & 27.7 & 29.8 & 5.2 & 2.6 & 5.1 & 43 & 129 & 86 & 254 & 205 \\
\hline & Gemmeiza-9 & 19.2 & 36.4 & 3.9 & 2.9 & 5.7 & 62 & 92 & 71 & 175 & 294 \\
\hline & Gemmeiza-10 & 22.4 & 34.4 & 4.3 & 2.6 & 4.7 & 55 & 105 & 61 & 209 & 235 \\
\hline \multirow{5}{*}{$\begin{array}{c}1.5 \mathrm{~kg} \\
\mathrm{Zn} / \text { fed. }\end{array}$} & Sakha-93 & 24.2 & 31.9 & 4.5 & 3.1 & 6.6 & 69 & 122 & 79 & 322 & 288 \\
\hline & Sakha-94 & 24.9 & 26.5 & 4.0 & 2.7 & 5.7 & 51 & 116 & 78 & 255 & 239 \\
\hline & Giza-168 & 15.8 & 31.9 & 5.5 & 3.0 & 6.9 & 61 & 174 & 76 & 344 & 282 \\
\hline & Gemmeiza-9 & 22.0 & 38.5 & 4.9 & 3.3 & 7.4 & 85 & 130 & 80 & 301 & 368 \\
\hline & Gemmeiza-10 & 22.7 & 37.7 & 4.7 & 2.4 & 4.8 & 56 & 163 & 64 & 286 & 254 \\
\hline \multirow{5}{*}{$\begin{array}{c}3.0 \mathrm{~kg} \\
\mathrm{Zn} / \text { fed. }\end{array}$} & Sakha-93 & 28.4 & 23.9 & 5.1 & 3.3 & 7.1 & 69 & 193 & 93 & 342 & 268 \\
\hline & Sakha-94 & 21.6 & 25.9 & 5.6 & 3.8 & 9.4 & 94 & 219 & 115 & 364 & 365 \\
\hline & Giza-168 & 30.7 & 30.2 & 5.9 & 4.5 & 9.0 & 89 & 167 & 126 & 328 & 277 \\
\hline & Gemmeiza-9 & 19.8 & 35.3 & 5.7 & 3.6 & 8.1 & 101 & 208 & 98 & 390 & 302 \\
\hline & Gemmeiza-10 & 24.1 & 35.8 & 5.8 & 4.2 & 8.7 & 100 & 199 & 116 & 383 & 368 \\
\hline \multicolumn{2}{|c|}{ L.S.D at 0.05} & 2.6 & 6.0 & 0.3 & 0.3 & 1.1 & 13 & 21 & 10 & 25 & 42 \\
\hline
\end{tabular}

4.3.Yield and yield components: Statistical analysis showed that there was significant effect of the interaction between wheat cultivars and zinc fertilizer levels for the studied characters in both seasons except plant height in second season (Table 6). Sakha-94 cultivar fertilized by $3.0 \mathrm{~kg} \mathrm{Zn/fed.}$ recorded superiority for plant height, number of spikes $/ \mathrm{m}^{2}$ and grain yield per fed. in first season, and second season for number of shoots/ $\mathrm{m}^{2}$ and number of grains/spike, where, the maximum means were 93.3, 747 and 13.8 in first season and 752 \& 38.2 in second season, respectively. Also, the highest values of number of grains /spike and 1000- grain weight (37.5 and 40.1, respectively) were achieved when Gemmeiza- 10 cultivar fertilized by $3.0 \mathrm{~kg}$ $\mathrm{Zn} / \mathrm{fed}$. in first season, while fertilized Gemmeiza-9 with $3.0 \mathrm{~kg} \mathrm{Zn} / \mathrm{fed}$. gave the highest values for 1000-grain weight and grain yield in second season. In addition of no fertilized by Zn, Giza-168 and Gemmeiza-10 cultivars recorded the lowest values grain yield (10.8 and 12.7 ardab/fed.) in first and second season, respectively. Zinc application treatments surpassed the soil fertility treatment in 2007/2008 and 2008/2009 seasons.

On the other hand, the lowest grain yields as well as yield components resulted from the untreated plants. Such effects of $\mathrm{Zn}$ application might be due to their critical role in crop growth, involving in photosynthesis processes, respiration and other biochemical and physiological activates and 
thus their importance in achieving higher yields. Similar results were reported by Welch et al. (1991), Hall and Williams (2003) and Kassab et al. (2004).

Table (6): Effect of interaction between cultivars and zinc application on plant height, shoots number, spikes number, yield and yield components of some bread wheat cultivars during 2007/2008 and 2008/2009 seasons

\begin{tabular}{|c|c|c|c|c|c|c|c|c|c|c|c|c|}
\hline \multirow[t]{2}{*}{ Treat } & \multirow[t]{2}{*}{ Cultivars } & \multirow{2}{*}{$\begin{array}{c}\begin{array}{c}\text { Plant } \\
\text { height } \\
(\mathbf{c m})\end{array} \\
1^{\text {st }}\end{array}$} & \multicolumn{2}{|c|}{$\begin{array}{c}\text { Shoots } \\
\text { /m² } \\
\text { (no) }\end{array}$} & \multicolumn{2}{|c|}{$\begin{array}{c}\text { Spikes } \\
/ \mathrm{m}^{2} \\
\text { (no) }\end{array}$} & \multicolumn{2}{|c|}{$\begin{array}{c}\text { Grains } \\
\text { / spike } \\
\text { (no) }\end{array}$} & \multicolumn{2}{|c|}{$\begin{array}{l}\text { 1000- } \\
\text { grains } \\
\text { (g) }\end{array}$} & \multicolumn{2}{|c|}{$\begin{array}{c}\text { Grain yield } \\
\text { / fed. } \\
\text { (ardab) }\end{array}$} \\
\hline & & & $1^{\mathrm{st}}$ & $2^{\text {nd }}$ & $1^{\mathrm{st}}$ & $2^{\text {nd }}$ & $1^{\text {st }}$ & $2^{\text {nd }}$ & $1^{\text {st }}$ & $2^{\text {nd }}$ & $1^{\text {st }}$ & $2^{\text {nd }}$ \\
\hline \multirow{5}{*}{ Control } & Sakha-93 & 82.3 & 762 & 795 & 502 & 484 & 29.5 & 35.6 & 32.9 & 37.2 & 12.2 & 16.9 \\
\hline & Sakha-94 & 93.6 & 704 & 817 & 477 & 531 & 33.5 & 35.0 & 33.8 & 34.1 & 13.8 & 14.1 \\
\hline & Giza-168 & 85.2 & 941 & 802 & 651 & 564 & 28.0 & 37.2 & 34.1 & 31.6 & 10.8 & 15.7 \\
\hline & Gemmeiza-9 & 92.7 & 860 & 755 & 613 & 453 & 27.0 & 35.0 & 39.3 & 35.1 & 11.1 & 15.0 \\
\hline & Gemmeiza-10 & 84.5 & 824 & 685 & 573 & 464 & 29.5 & 37.8 & 34.9 & 37.3 & 12.0 & 12.7 \\
\hline \multirow{5}{*}{$\begin{array}{c}1.5 \mathrm{~kg} \\
\mathrm{Zn} / \mathrm{fed} .\end{array}$} & Sakha-93 & 89.7 & 843 & 695 & 621 & 488 & 36.0 & 36.4 & 38.4 & 40.1 & 11.9 & 14.7 \\
\hline & Sakha-94 & 86.2 & 778 & 805 & 551 & 547 & 36.0 & 34.9 & 34.6 & 38.5 & 12.6 & 14.6 \\
\hline & Giza-168 & 91.3 & 879 & 791 & 617 & 389 & 35.0 & 35.4 & 33.8 & 35.3 & 11.9 & 15.3 \\
\hline & Gemmeiza-9 & 87.6 & 840 & 797 & 627 & 532 & 29.5 & 33.8 & 34.7 & 38.9 & 12.5 & 18.3 \\
\hline & Gemmeiza-10 & 91.7 & 750 & 794 & 560 & 649 & 30.5 & 36.3 & 37.6 & 37.7 & 12.6 & 15.0 \\
\hline \multirow{5}{*}{$\begin{array}{c}3.0 \mathrm{~kg} \\
\mathrm{Zn} / \mathrm{fed}\end{array}$} & Sakha-93 & 83.4 & 674 & 583 & 668 & 581 & 36.8 & 36.3 & 38.3 & 40.4 & 11.5 & 17.4 \\
\hline & Sakha-94 & 93.3 & 780 & 752 & 747 & 650 & 33.5 & 38.2 & 39.5 & 38.0 & 13.8 & 16.3 \\
\hline & Giza-168 & 88.9 & 842 & 738 & 702 & 683 & 31.0 & 35.0 & 33.1 & 35.7 & 13.3 & 14.5 \\
\hline & Gemmeiza-9 & 89.5 & 739 & 694 & 655 & 664 & 37.0 & 34.2 & 38.5 & 40.4 & 11.9 & 17.4 \\
\hline & Gemmeiza-10 & 89.6 & 679 & 697 & 648 & 607 & 37.5 & 34.3 & 40.1 & 39.0 & 13.7 & 16.5 \\
\hline \multicolumn{2}{|c|}{ L.S.D at 0.05} & 6.8 & 69 & 55 & 43 & 32 & 2.6 & 1.4 & 1.6 & 1.4 & 0.6 & 1.5 \\
\hline
\end{tabular}

\section{CONCLUSION}

It could be concluded that under sandy soil condition zinc application with $3.0 \mathrm{~kg} \mathrm{Zn/fed}$. in form of zinc sulphate $\left(\mathrm{Zn} \mathrm{SO}_{4} .7 \mathrm{H}_{2} \mathrm{O}\right)$ could be used to obtain high grain yield and yield components of wheat plants. Also, to obtain the highest wheat shoots uptake of $\mathrm{P}, \mathrm{K}, \mathrm{Zn}$ and $\mathrm{Fe}$, zinc application should be applied at $3.0 \mathrm{~kg}$ per fed. On the other hand, the application of $3.0 \mathrm{~kg} \mathrm{Zn}$ per fed. is recommended for Giza-168, Sakha-94 and Gemmeiza-9 cultivars at sandy soils conditions of El-Ismailia Governorate.

\section{ACKNOWLEDGEMENTS}

This work was carried out as a part of the activities of the EgyptoGerman Project" Micronutrients and other Plant Nutrition Problems in Egypt" conducted by National Research Centre, Cairo (Coordinator: Prof. Dr. M.M. El-Fouly) and the Institute of Plant Nutrition, Technical University of Munich (Prof. Dr. A. Amberger). 


\section{REFERENCES}

Abd El-Gawad, A.A.; K.A. El-Shouny; S.A. Saleh and M.A. Ahmed, (1987). Partition and migration of dry matter in newly cultivated wheat varieties. Egypt. J. Agron., 12: 1-16.

Ahmed, A.G.; M.S. Hassanein and M.M. El-Gazzar, (2006). Growth and Yield Response of Two Wheat Cultivars to Complete Foliar Fertilizer Compound "Dogoplus" Journal of Applied Sciences Research, 2(1): 2026.

Ankerman, D.; and L. Large,(1974). Soil and Plant Analysis. A\&L Agricultural Laboratories. Inc, New York, USA.

El-Fouly M.M.; ZM. Mobarak and ZA. Salama, (2010). Improving tolerance of faba bean during early growth stages to salinity through micronutrients foliar spray. Not. Sci. Biol., (2): 98-102 .

El-Fouly, M.M.; A.F.A. Fawzi; A.H. Firgany and F.K. El-Baz, (1984). Micronutrient status in selected areas and crops in Egypt in relation to NPK. Comm.. in Soil Sci. \& Plant Anal., 15: 1175-1189.

El-Habbasha, S.F.; M.M. Tawfik and, H. Mohamed, Magda (2008). Response of two wheat varieties to partial replacement of recommended nitrogen fertilizer by bacterial inoculations. Egypt. J. Agron., 30(2): 187-200.

Graham, R. D.; and R.M. Welch, (1996). Breeding for staple food crops with high micronutrients density. Agricultural strategies for micronutrient working paper no. 3. International Food Policy Research Institute, Washington, D.C.

Hall, J.L. and L.E. Williams, (2003). Transition Metal Transporters in Plants. J. Exp. Bot., 54: 2601-2613.

Hassanein, M.S. (2001). Effect of variety and nitrogen foliar fertilizer compound under water stress levels on growth, yield and yield components of wheat (Triticum aestivum L.) in Newly Cultivated land. Egypt. J. Agron., 23: 111-131.

Hassanein, M.S. and A.M. Gomaa, (2001). Productive efficiency of certain wheat cultivars biofertilized with phosphate-solubilizing Bacilli, Azotobacter and yeast under varying levels of phosphorus Annals of Agric. Sci. Moshtoher, 39(4): 1907-1922.

Hassanein, M.S.; M.A. Ahmed and D.M. El-Hariri, (1997). Response of some wheat cultivars to different nitrogen sources., J. Agric. Sci. Mansoura Univ., 22(2): 245-256.

Jackson, M.L. (1973). Soil chemical analysis. Prentice- Hall Inc. N.J., U.D.A.

Judrth, A.; C. Rosen and L. Marc, (1977). Zinc, Iron, and Chlorophyll metabolism in zinc-toxic corn. Plant Physiol., 59: 1085-1087.

Kassab, O.M.; H.A.E. Zeing and M.M. Ibrahim, (2004). Effect of water deficit and micronutrients foliar application on the productivity of wheat plants. Minufiya J. Agric. Res., 29: 925-932. 
Khan, M.A.; M.P. Fuller and F.S. Baloch, (2008). Effect of soil Applied zinc sulphate on wheat (Triticum aestivum L.) grown on a calcareous soil in Pakistan. Cereal Res. Comm., 36: 571-582.

Lindsay, W.L. (1972). Zinc in soils and plant nutrition. Adv. Agron., 24:147186

Marschner, H. (ed.) (1995). Mineral Nutrition of Higher Plants. New York Academic Press, $649 \mathrm{p}$.

Mordvedt, J.J. and R.L. Gilkes, (1993). Zinc fertilizers. In: Zinc in Soils and Plants. A.D.Robson (ed.). Kluwer Academic Publishers, Dordrecht, the Netherlands, pp. 33-44.

Pugnaire, F.; L.S. Enddoiz and J. Pardos, (1994). Constraints by water stress on plant growth. Handbook of Plant and Crop Stress.(Ed. Mohammed Pessarakli, Chap. 11, pp. 147-259.

Sarhan, A.A. and M.F. Abd El-Maksoud, (2002). Response of some wheat cultivars to soil and foliar application of different levels of nitrogen under sandy soil conditions Egypt J of App Sci., 17(11): 543-560.

Snedecor, G.W. and W.G. Cochran, (1967). Statistical methods, 6th Edition, lowa State College, Ames lowa, U.S.A.

Takkar, P.N. and C.D. Walker, (1993).The distribution and correction of zinc deficiency. P. 151-165. In: Zinc in Soils and Plants. Kluwer Dordrecht, the Netherlands.

Voldeng, H.D. and G.M. Simpson, (1967). Leaf area as an indicator of potential grain yield in wheat. Can. J. Plant Sci., 47:359-365.

Waller, R.A. and D.B. Duncan, (1969). A bays rule for the symmetric multiple comparisons problem. Am. Stat. Assc. J. December. 1485.

Welch, R.M.; W.H. Allaway; W.A. House and J. Kudata, (1991). Geographic Distribution of Trace Element Problems. In: Micronutrient in Agriculture, Mortvet, J.J., F.R. Cox, L.M. Shuman and R.M Welch (Eds.). SSSA, Madison, WI. USA, pp: 31-57.

Yilmaz, A.; H. Ekiz; B. Torun; I. Gultekin; S. Karanlik; S.A. Bagci and I. Cakmak, (1997). Effect of different zinc application methods on grain yield and zinc concentration in wheat cultivars grown on zinc-deficient calcareous soils. J. Plant Nut., 20: 461-471.

Zaki, N.M.; M.A. Ahmed and M.S. Hassanein, (2004). Growth and yield of some wheat cultivars irrigated with saline water in newly cultivated land as affected by nitrogen fertilization Annals of Agric. Sci., Moshtohr. 42(2): 515-525.

Zhoori, A.; M. Rahemi and B. Kholdebarin, (2009). Ameliorative effects of zinc on Pistachio (Pistacia vera L.) growth under salt-affected soil conditions. Res. J. Environ. Sci., 3: 656-660. 
تـأثير اسـتخدام الزنـك على صفات النمـو وامتصــاص العناصر والمحصـول لبعض أصناف القمح تحت ظروف الأر اضير الرئ الرملية

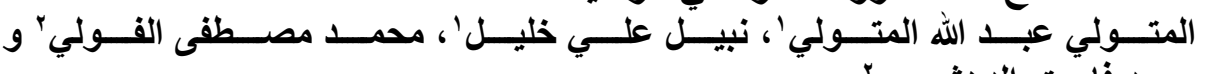

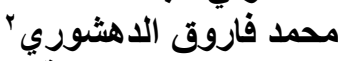

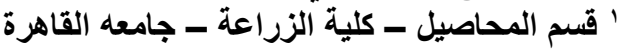
r قسم تكنولوجيا التسميد ـ المركز القومي للبحوث ـ ـ الدقاهي ـ القاهرة - جمهورية مصر العربية

نم إجر اء تجربتان حقليتان بمحطة التجارب الزراعية بالإسماعيلية- محافظة الإسماعيلية

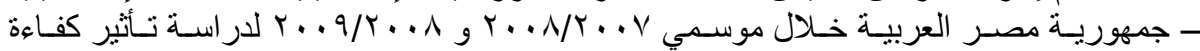

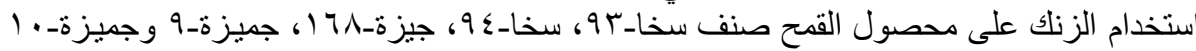

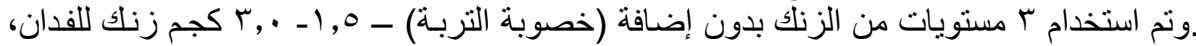

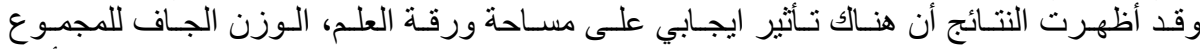

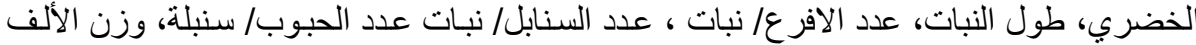

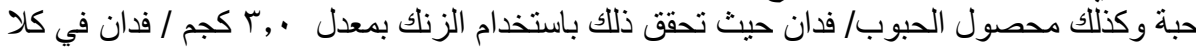

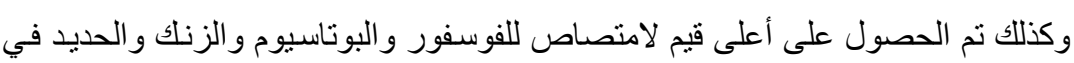

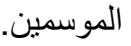

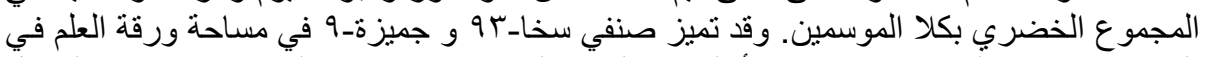

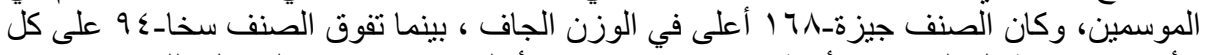

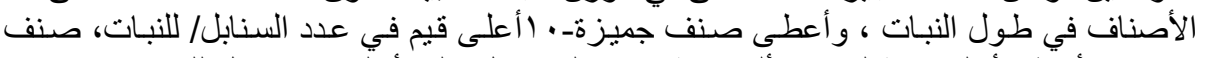

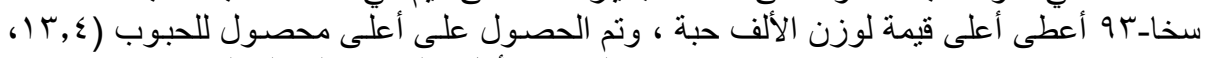

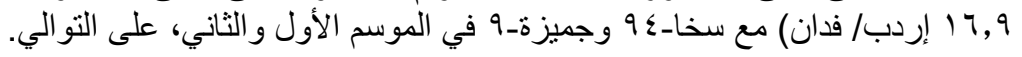

كلية الزراعة - جامعة المنصورة قام بتحكيم البحث كلية الزراعة - جامعة القاهرة

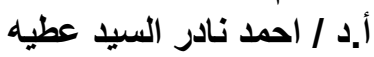
أ.د / أد / احمف علي عبد العبد الع اله 